\title{
The Legislative Crisis
}

\author{
JOSÉ EDUARDO CARDOZO
}

$\mathrm{E}$

CONOMIC AND SOCIAL TRANSFORMATIONS that have taken place since the beginning of the 1lth Century on the European continent resulted in the birth of new political and judicial institutions. It could not have been different. Economy, society, law and political power are always integrated in the universe of relations that constitute a specific historical moment.

This new institutionality did not spring from a model conceived by a genial thinker on a rainy night. Nor was it imposed on feudal rulers and kings overnight, by swords and cannonballs by a warrior general specializing in the strategies of war. It was built slowly, by facts and minds, over the long decline of the feudal system. The beginnings of this system were born in the relations that created the capitalist mode of production and imposed new ways of exercising power. Private dependency, constituted by the stepped system of service characteristic of the Middle Ages, was put in question by a gradually increasing process of centralized power. Individuals, day after day, became more subject to their kings. The power of the king began to no longer stand

on dependencies derived from personal property, birth, wedding or sale, but from the power of his military and police. The sovereign was to no longer exclusively represent their princes or counts, but to protect the interests of all people who would submit to his power. Beside the dependence of the officers or servants to their masters, a relationship of dependency, based on public law gradually developed between the king and his people. (Fleiner-Gerster, 2006, p.181)

Historical changes dictated growing needs imposed by the beginning of the capitalist mode of production that created this new institution. The free flow of capitalist economic relations demanded the abolition of slavery and "formal equality" in relations between humans, so that blue blood was no longer a precondition for the exercise of power. The relations of dependency between the "new rulers" and ordinary people ceased to be based on tradition or "divine power". New forms of legitimation of power were born as a result of the demands of "social governance."

It was within this historical context that the "Modern State" was born: a state characterized as a unit of power exercised over a people living in a territory in which this same power is imposed in a rational and centralized manner, configuring itself, from an external point of view, as independent and autonomous, i.e. as sovereign. People, territory and sovereignty, therefore, are its essential elements and shapers. 
As part of its structure, the affirmation of the primacy of law as an instrument of collective will and configurator of the "public interest" as well as the adoption of the tripartite theory of state power gave birth to the concept of rule of law. To some extent a synthesis of the thoughts of Montesquieu and Rousseau, this rule of law, in a sovereign manner, within its territory, exerts its power over the people, but with respect to the limits imposed by the laws that are produced. Within it a person or a group of people can not institutionally concentrate power. Therefore, its constituent parts should be distinct organic complexes, autonomous and independent, acting in the interest of harmony, producing laws (the Legislative), executing them (the Executive) and also judging "fairly" those who transgress them(the Judiciary).

The passing of this model of the State from the world of ideas to the world of facts derives from the transformative actions of the North American Declaration of Independence in 1776, to the birth of the Constitution of the United States, and the blood shed on French soil during the bourgeois Revolution of 1789. It has since then become the model adopted by many countries of the world.

At the beginning of the $21^{\text {st }}$ century, however, we are undergoing times of profound transformations. Time seems to run faster. Every day the technological revolution produces changes of habit and behavior. By not having the speed of the internet, newspapers no longer deliver the "Latest News." Virtual relationships have begun to develop new ways of living and love relationships. In the stock exchange, operators' cries are replaced by electronic auctions that every moment securely perform thousands of business operations. It is no longer necessary to go to stores for shopping; banking operations no longer require a trip to the bank. The telephone goes with us as though it were an extension of our bodies. With it we speak to people on the opposite side of the globe, listen to music, watch television, do calculations, know where we are via satellite, make recordings, take photographs, receive the news and stock market quotations on-line.

These changes also affect other aspects of life. In a globalized world, an economic crisis in one country immediately affects the planet. Capital moves dizzily, back and forth, bringing U.S. dollars to one side of the world to the other at the speed of light. Stable banks break and conglomerates are formed overnight. The market, the old place where business was done, has become a metaphysical entity, unstable, intensely sensitive, whose incomprehensible essence intimidates governments and embodies an angel or a demon.

Given this, will it still be possible to believe that political institutions will remain unaffected by this new historical reality? That human relations, economic life and forms of social interaction are being transformed at a breakneck pace and institutions will remain untouched?

Without the gift of foresight, but with the ability to read signs and draw conclusions, I believe not. There are objective indicators that the Law of the 
State, at least in its classic, bourgeois formulation, can no longer respond to the impositions dictated by this new moment of history. One of these indicators seems to be the crisis which, world wide and particularly in Brazil, has affected one of its sustaining pillars: the Legislature.

\section{The Crisis of the Legislature: Dysfunctional and Unrepresentative to the Demands of the Present Historical Time}

World wide, Parliament is experiencing a crisis and loss of institutional legitimacy.

This situation is paradoxical. Nowadays, when some countries are living under the bayonets and guns of a dictatorship, strong, free parliaments, with secure constitutional guarantees, are seen as necessary for the guarantee of freedom and democracy. At such moments, fragile and frightened, society returns to the past and to the historical origins of parliamentary life. It recalls in the full dimensions what gave rise to the Parliament in medieval England, as a major source for the limitation of power. A free Parliament, constituted of elected representatives, is defended as an indispensable institution for establishing limits to the exercise of power, for respect for plurality of opinions and for the formulation of legitimate, fair and balanced State policies.

When dictators fall, although, like the phoenix, democratic life is reborn, little time is required for Parliament to come to be seen as an unproductive, slow, parasitic institution occupied by useless, inept or hypocritical "politicians, "true leeches that live off the Treasury greedily gorging on privileges and "perks" that they can gain from their pompous and "useless" power. What, finally, do your "excellencies" serve? Implicitly or explicitly this is the question that runs through the streets, to houses, bars, barber shops and hairdressers when democracy is in the air. "For nothing" or "to steal," answer the "sincere" who say what think. "Men should not be confused with the institutions," answer the convinced democrats or those who, out of intellectual fashion, fearing to deviate from the "politically correct" in times of freedom, humbly modulate their feelings and understanding, at least until dictatorships return to fashion.

It is true that this pejorative assessment in relation to Parliament is not uniform around the world. There are countries where the democratic and cultural roots are stronger. And in them the criticism is subtler and not even superficially is directed toward the need for eradication of the institution. But in others the feeling of aversion is so strong that even the most democratically oriented person cannot presume to imagine the possibility of the voting masses coming to argue for the extinction of parliamentary institutions. In the end, in such cases, the historical possibility of a dictatorship being democratically approved by popular vote is real. A democrat from our time might be forced to acknowledge, against his will, that "Democracy must have as a limit, always whenever necessary, the non-democratic expression of its own existence". 
Whether it is or is not true in general, a common criticism of Parliament concerns the slowness of its decisions. There are even those who propose, taking as true the classic affirmation that the production of laws should be compared to the production of sausages, that the efficiency of a Legislative House ought to be measured by the number of laws that it approves. "The more laws that are approved, the better for the people," in the same way that "the more sausages produced, the better for the owner of the factory" seems to be the rationale on which this curious measurement of parliamentary productivity is based. It is clear that this understanding follows from the maxim "every new law is a good law," when in truth any less mercantilist or "sausage" way-of-thinking of legislative life shows us the opposite. Many times, for social life it would be better not to pass any law. And for the public interest, the forces and energy spent so that nothing will alter at the time could be more productive than the approval of certain "sausage laws."

The fact is, however, that Parliamentary decision-making processes are slow. And, we can say in defense of the obvious, that it is entirely natural that they should be. Any and all decision-making process that travels so many varied collegial roads to its constitution is much slower. It always requires debate, respect for different opinions, development of convictions and decisions by majorities. Actually it is a natural law, intrinsic to the facts of life, that democratic decisions will be much slower than authoritarian decisions. A despot or a dictator can decide whatever he wants, as quickly as desired. He consults whoever he wants to, if and when he desires to hear before deciding. For him the distance between wanting and the expediting of an act of government is only the distance between the brain and the hand that holds the pen that signs the signature. There is no divergent thinking, no need to convince anyone else or form a majority. The only obstruction that could exist is a lack of ink in the pen.

Indeed, the very logic that induced thinkers to suggest that the law should be approved by Parliament, a collegial body that decides in accord with the opinion of the majority, also suggests that the execution of the law should be undertaken by a hierarchical Power such as an army. In this manner of thinking the law is the greater act, the act which restricts social behavior. For this "no one can do, or exempt (him or herself) from doing something unless forced by law" (principle of legality), a law that should be a decision approved by a majority of the representatives elected by society. It demonstrates the collective will and the public interest has been reached. On the other hand, its mere implementation should be understood as simple compliance with what has been already decided by the majority of representatives of the community by a person who is conventionally known as a "public official." As already said, someone who is simply an administrator by definition "is without proprietary interest." The public administrator is not a "proprietor" of the "res public"or owner of the public interest. The "proprietorship" is the people, i.e. those people living in the territory of a sovereign state and in the name of which "all of the power is exercised."

And thus is our system. And so that is how the problems dictated by modern 
reality appears, among them the "slow decision-making" of parliaments.

Indeed, in fast moving times such as ours, where problems are born from events that reverberate within seconds to other continents the requirement for rapid decision-making is increasing. Today economic authorities must decide immediately what to do in the economies of their countries on the daily emerging facts, health authorities must take immediate preventive measures to prevent or minimize outbreaks that can be generated in another corner of the world, and the police need legal means and effective instruments to combat new criminal procedures that appear daily. There are hundreds of everyday situations that a government has to decide on the spot with agility and speed far superior to that which was demanded in the past. The time to pass a law can be fatal for the preservation of dominant interests in society.

It is for this reason that so many Constitutions are prepared so that the exercise of a legislative act does not reside solely concentrated in the hands of the Legislature. A typical example is our "provisional measures" which, although not "laws" in the strict sense of the term, are dictated by the Chief Executive and have legal force equivalent to those enactments.

Naturally, this condition that requires immediate decisions, dictated by the new times, have, around the world, been placing the decision-making process in the hands of the Executive with a substantial loss of policy-making space for the Legislature. Increasingly parliamentary procedures are less able to respond to the circumstances posed by modern life and the demands of a rapid, integrated, online historical reality. A legislatures' natural, inherently slow democratic process is the result of its own plural, procedural and ritualistic composition, moving in a direction opposite to the historical dynamic of social facts.

There are however, cases in which the "Legislative space" is unable to be claimed by the Executive branch, but instead is assumed by the Judiciary. Drawing on legal institutions for fixing the interpretation of the rules operative in many countries, judges, under the guise of "interpreting the law," assume the role of "legislature". Under the rhetoric of "pronouncing the law," "create" the law, without having this right.

This problem of legislative power being claimed by other branches has often been analyzed only through superficial consideration of the problems of a Parliament or a legislature. It is true that, at times, these problems are aggravated by specific and time-based crises. However, what cannot be lost sight of is that the problem is not merely subjective, owing to certain parliamentarians. It is an objective, systemic problem that is dictated by changing times. The march of history undermines the traditional Parliament and the principle of democratic legality. Increasingly, calls into question the rule of law, its pillars of support and the bourgeois conception of democracy.

Another systemic problem, imposed by the historical moment in which we live, refers back to the clash between representative democracy and the instruments of direct democracy. 
Traditionally, the most common legitimizing argument we hear for the election of representatives of the people for the approval of its laws is the real impossibility, the difficulty, of citizens directly express their will in the adoption of standards that should direct their conduct. Citizens can not physically meet in assemblies to decide what should be their laws. Therefore, representatives must be elected in order to, in assembly, decide the general rules that will govern social life.

Therefore we think to ourselves. With high security standards technological change may soon allow citizens to vote directly from their own computers for the formulation of laws. Casual discussions and interactive debates can be conducted on the Internet whenever desired. Direct democracy, exempting intermediaries (i.e. parliamentarians) will be able to be exercised with no difficulties.

The question will then be: why should there be a Parliament if the people can directly express their will for the approval of its laws?

It is perhaps possible in a philosophical exercise or by great perception to imagine that "Parliament," in fact, may be expendable in the development of democratic decision-making in the State of the future. Its existence within the very premises of a Democratic State of Law will then be questioned and will no longer be a requirement imposed from a prior model, but an option.

It is said that the need for deep and detailed studies on various matters, free from the momentary passions dictated by common sense and the shifting waves of volatile public opinion, can never eliminate the management of the state and the existence of elected representation in future democracies. To a certain extent I tend to think so. However, it is inevitable that with time such questions will emerge. Questioning that, by not being merely speculative, can lead to profound changes in our way of experiencing democracy.

What garb will the Legislative Branch then wear, with the changes to come? How will the systemic democratic deficit be fed that will be brought about by the usurpation of the functions of the Legislature by the Executive or the Judiciary (or both) in the State in the $21^{\text {st }}$ century?

Certainly, we can now say, recalling Hamlet, "that is the question."

\section{The Crisis of the Brazilian Legislative Branch: The Inadequacy of the Political System}

In addition to the general problems addressed here, the crisis of the Legislature in Brazil is further aggravated by the specific situations generated by our political system.

In the first place it must be noted that our proportional election system is not only anachronistic, but also presents undemocratic deviations. Anachronistic because, contrary to times of republican demands and impersonality, the whole election process is based on the vote that the voter gives to the candidate as a person. Greater value is thereby placed on the personal characteristics of the candidate than on their political, ideological and program-based vision. 
The consequence is obvious. Since in our system the electoral contest by proportional vote is spread among a high number of candidates to be chosen for each vacancy within the larger universe of voters who choose them, the difficulty of gaining personal knowledge of the candidates' ideas inevitably results in a major dose of depoliticization of choice. The vote for the future parliamentarian is made by "beauty", out of "sympathy," for "artistic" or "sporting" gifts. The presentation and knowledge of the candidate as a person by the media are almost always the decisive electoral lines for a choice, due to the suppression of debate and the general ignorance of the different "personalities" running for the Legislature vacancies.

Naturally reducing the selection criteria to these kinds of personal "attributes" or to the processes of media exposure produces bizarre and questionable election results, at least in terms of what, in theory, could be considered a "good Parliamentary representation."

Furthermore this personalizing process strengthens the personal relations between voters and the elected while weakening the formation of political parties with their ideological and programmatic identity. Therefore, this patronage becomes fertile ground for the "process of capturing votes" to flourish.

Perhaps this is one of the main reasons why in Brazil we have so many "legends" and so few political parties in the proper sense of this expression, which causes serious problems for the Parliament and governance. The formation of "parliamentary majorities," indispensable to any government, nearly always, fails to go beyond understandings or pledges between parties. It is the "individual" needs of parliamentarians that are addressed so that, by occupying "positions of power in the state bureaucracy" (recommending positions in the Executive) and receiving the benefits of administrative actions that are focused on caring for their electoral "patrons," or even negotiating "non-republican" advantages, they may come to have good conditions for their future electoral contests.

Therefore, note that this "personalized" electoral reality also facilitates democratic deviance. Although voters choose the person they want to elect, under current electoral law votes are tallied by party affiliation (or coalition) in order to defining the number of seats they will occupy. Seats are filled based on the order of the top vote-getting candidates in each party. Where an elector may vote for the personage of one candidate, without having considered the candidate's party, another candidate from the same party, with nothing else in common, may in theory come to be elected.

This fact further will be even more exasperating if we note that the majority of Brazilian voters, possibly ignore this manner of distributing seats in Parliament, not knowing they can vote for a candidate and elect another who they would never have voted for.

And secondly, we must emphasize that to a large extent this electoral system generates the structural corruption we have in our country. The campaigns for the Parliament, to the extent that they are conducted individually, 
require each candidate to chase after funding for the financial resources. Of course, these resources are decisive for the election. The more money a candidate has, the greater the possibility of emerging victorious in this widespread universe of competitors.

Therefore, the abuse of economic power and the lack of parity among candidates are an inevitable result of this system. The lack of effective oversight of the entire electoral system is a reality. And thus was born the promiscuous bonds between donors and candidates. Making electoral donations in exchange for favors or future advantages is a reality in our political life.

This system provides incentive for advantageous corruption scandals and, consequently, a tarnished image of Parliament. In times of free press and independent and republican state bodies investigating acts of misconduct and election aberrations, a subterranean reality always emerges. And when the mantle of a hypocritical system does not cover over its hidden parts, the crisis flourishes.

\section{Conclusion}

The time has come to go beyond common sense in discussing the crisis that now affects the parliamentary institutions, both in the world, and, in particular, Brazil. The Manichean approach that classifies members of the "political class" in terms of "good" and "evil" can, on the one hand, trigger a higher level of primary awareness by voters, while on the other hand it prevents knowledge of deeper causes of problems. It is clear that "bad" Parliamentarians should be banned by the forfeiture of their office or from voting. It is quite clear that a discussion, even put in Manichean terms, still has the advantage of the fact that it demolishes the pathetic vision of "steals but does" or the idiotic dogma that" every politician is a parasite, a thief, or both." But this is not sufficient.

The crisis of Parliament has deeper causes. It should be discussed in sunlight, radically, from knowledge of the contradictions generated by the current historical reality. It is the full understanding of its roots, with all of their ramifications, which will allow us to build a democratic solution for the future. A new political system? A new Parliament? A new structure of the Powers of the State? A new democratic State?

History, of course, will tell. 
Bibliographic Reference

FLEINER-GERSTER, T. General theory of the State. São Paulo: Martins Fontes, 2006.

José Eduardo Cardozo is a master, a doctoral student, a law professor at PUC-SP, at Paulista School of Law and at the Marcato Course. He was secretary of government of the municipality and president of the Municipal Chamber of São Paulo. He is currently federal deputy for and Secretary-General of the Workers' Party (PT). @ - dep. joseeduardocardozo@camara.gov.br

Received on 25.9.2009 and accepted on 29.9.2009.

Translated by Cary Wasserman and Valéria Wasserman. The original in Portuguese is available at http://www.scielo.br/scielo.php?script=sci_issuetoc\&pid=0103401420090003\&lng=pt\&nrm=iso. 